\title{
MOLLA SADRÂ'NIN HUDÛS YORUMU*
}

\author{
Mahmut Meçin \\ Dr., Milli Eğitim Bakanlığı, Mardin \\ PhD, Ministry of National Education, Mardin \\ mahmutmecin@gmail.com \\ orcid.org/0000-0002-4468-565X
}

\author{
Ali Çaksu \\ Doç. Dr., Yıldız Teknik Üniversitesi Fen Edebiyat Fakültesi, İstanbul \\ Associate Professor, Yıldız Teknik University Faculty of Arts\&Science \\ alicaksu@yahoo.com \\ orcid.org/0000-0001-7678-0638
}

\section{Öz}

Âlemin zaman içinde vücûda gelip gelmediğine dair tartışma düşünce tarihinde kadîm bir geçmişe sahiptir. Platon öncesi döneme kadar izleri sürülen söz konusu tartışma İslâm düşünce tarihinde de önemli bir yer işgal eder. Kelâm ile felsefe ekolleri arasında cereyan eden münazaralarda kelâmcılar, âlemin yokluğu üzerinde bir zaman geçtikten sonra yaratıldığını ileri sürerken filozoflar ise Allah'ın âlemden zamansal olarak değil zatî bir öncelikle mukaddem olduğunu savunurlar. Klasik dönem sonrası devam eden tartışmalarda probleme dair yeni çözümler ortaya konulmuştur. Bu makale klasik dönem sonrası İslam felsefesinin önemli simalarından biri olan Molla Sadrâ'nın hudûs anlayışını konu almaktadır. Kendinden önceki hudûs yaklaşımlarını değerlendiren Molla Sadrâ, hareket-i cevherî teorisi bağlamında probleme yeni bir yorum getirir. Sadrâ'nın yorumunu belirgin kılmak için İslâm düşünce geleneğinde oldukça canlı bir tartışma zeminine sahip olan meselenin tarihî arka planı netleştirilmeye çalışılacaktır. Hareket ve zamanı, seyyal varlığın birer boyutu olarak gören Sadrâ'ya göre hareketin bizzat kendisi anlamına gelen yaratmanın olmadığı mevhum bir zamanın varlığı söz konusu olamaz. Bu anlamda âlem, öncesinde yokluk olan muayyen bir zaman diliminde yaratılma anlamında hâdis değil, yaratmanın zaman mecrasında gerçekleşmesi anlamında hâdistir. Metafiziğin en girift meselelerinden biri olan bu problem hakkında Molla Sadrâ'nın yorumu kelâmcılar ile filozoflar arasında kısırdöngüye dönüşen tartışmalarda bir uzlaştırma ve inkişaf sadedinde görülebilir.

Anahtar Kelimeler: Kelâm, Molla Sadrâ, Hudûs, Kıdem, Hareket-i cevherî, Zaman.

\section{MULLA SADRA'S INTERPRETATION OF HUDŪTH}

\begin{abstract}
The debate over the question whether the universe originated in time goes back to the pre-Plato period in the history of thought. It occupies an important place in the history of Islamic thought. In the debates between Muslim theologians and philosophers, the theologians claim that the universe was created after a period of time has passed on its non-existence, while philosophers argue that the relationship between God and the universe is not timewise, but it is rather essence-wise (zâtî): God precedes the
\end{abstract}

Bu makale Molla Sadrấda Zaman Anlayışı ve Tarih Bilinci (Yıldız Teknik Üniversitesi, Sosyal Bilimler Enstitüsü, İstanbul, 2019) adlı doktora tezimizden üretilmiştir.

Geliş Tarihi: $03.09 .2019 \quad$ Kabul Tarihi: $17.12 .2019 \quad$ Doi: $10.18317 /$ kaderdergi.615156


universe in terms of essence. In the ongoing debates after the classical period, new solutions to the problem are presented. This article focuses on the Mullā Sadrā's understanding of origination, who is one of the important figures of post-classical Islamic philosophy. Mullā Sadrā, who evaluates previous approaches to origination, suggests a new explanation to the problem within the context of the theory of substantial motion (al-harakat al-jawhariyyah). In order to make clear his interpretation, the historical background of the issue which is a very lively debate in Islamic thought tradition will be tried to be clarified. According to Sadrā, who sees motion and time as a part of active existence, there can be no time when there is no origination, which also means motion. In this sense, the origination of the universe is not in the sense that it was created in a certain time, which was previously absent, but in the sense that its creation (origination) takes place all the time. Mullā Șadrā's interpretation of this problem, one of the most intricate issues of metaphysics, can be seen as a model of reconciliation and development in discussions that have turned into a vicious circle between theologians and philosophers.

Key Words: Kalām, Mullā Sadrā, Origination (hudūth), Eternity (qidam) Substantial Motion, Time

Atıf / Cite as: Meçin, Mahmut-Çaksu, Ali. "Molla Sadrâ'nın Hudûs Yorumu”. Kader 17/2 (Aralık 2019): 475-495.

\section{SUMMARY}

The debate over the question whether the universe originated in time goes back to the pre-Plato period in the history of thought. It occupies an important place in the history of Islamic thought. The issue has both ontological and cosmological aspects because it reveals a concept of God based on the question whether God created the universe in time and how it relates to the universe. In the debates between Muslim theologians and philosophers, the theologians claim that the universe was created in time, while the philosophers argue that the order of precedence between God and the universe is not timewise but essence-wise (dhât $\hat{\imath})$. In Essential origination (dhâtî $h u d \hat{u} t h$ ), the cause precedes the effect only ontologically, while in temporal origination, the cause precedes the effect both ontologically and temporally. The theologians, who argue that the universe was created by God in a certain time, formulate their theses with the concept of huduth. On the other hand, the Peripatetic philosophers approach the problem through the distinction between necessary and possible existence, arguing that an essential or ontological origination is also possible. This difference of interpretation deriving from the views of both sides about God and creation is considered by some to be a distinction of faith and unbelief, while for others it is a discussion of terminological and mere naming. In the ongoing debates after the classical period, new solutions to the problem have been put forward, apart from the temporal and essential origination, which are advocated as an effort to explain how the universe was created. One of these solutionsis the dahri huduth put forward by Mir Dāmād while the other hudūth view was developed by Mullā Sadrā in accordance with his theory of substantial motion (al-harakat al-jawhariyyah).

This article focuses on Mullā Sadrā's understanding of origination of, who is one of the important figures of post-classical Islamic philosophy. Mullā Sadrā, who evaluates previous approaches to origination, offers a new explanation to the problem within the context of the theory of substantial motion. Sadrā argues that 
time which he describes as the measure of dynamic movement inherent in existence began with the movement of the universe, and that the universe was always re-created with a temporal origination. Sadrā draws attention to the importance of the concept of time in the solution of the problem and sees movement and time as a dimension of dynamic existence, there can be no time when there is no origination which is to say, motion. In this sense, the origination of the universe is not in the sense that it was created in a certain time, which was previously absent, but in the sense that origination takes place all the time. Sadrā's view of time refers to the quantity of substantial movement, which has together with the origination and has never been interrupted. There is no beginning of such an origination and time because origination is not separate from God. Although Sadrā calls his understanding of origination (huduth) as temporal origination, his understanding of origination is different from the temporal origination of the theologians who accept the existence of time before the origination of the universe and foresee the origination of the universe at a certain point of such a time. According to him, there is no time before the origination of the universe, since time is a mental concept which is derived from the dynamic structure of the universe. Mullā Șadrā's interpretation of this problem, one of the most intricate issues of metaphysics, can be seen as a model of reconciliation and development in discussions that have turned into a vicious circle between theologians and philosophers.

When we look at the approaches in relation to the problem of origination, we can say that in all approaches, including Mullā Sadrā's understanding, the concept of time acts like a triangulation point which determines the course of all discussions and differentiates these approaches from one another. In our opinion, the main reason for the debate that has turned into a vicious circle as to whether God precedes the universe in terms of time or essence can be explained by the fact that the human mind, which is dependent on time, is unable to grasp a timeless field or timelessness. For this reason, despite the aforementioned theories about the solution of the problem of origination in Islamic thought tradition, the questions about origination are still not fully answered in our minds. It's possible that these questions will find an answer if we are able to follow the path that Islamic thinkers such as Sadrā, who made significant improvements by benefitting from the previous traditions of thought, have paved the way for us to develop new explanations.

\section{Giriş}

Klasik metafiziğin önemli problemlerinden biri olan âlemin zamansal açıdan mahiyeti, İslâm düşünce geleneğinde kelâmcılar ile filozoflar tarafından farklı yorumlanmış ve geniş bir müktesebat oluşturmuştur. Kelâmcılar ile filozoflar arasındaki hararetli tartışmaların ana gündeminde yer alan söz konusu problemin özü şöyledir: Kelâmcılar, âlemin kadîm olduğunu iddia etmenin Tanrı'dan başka ezelî varlıkların kabul edilmesi anlamına geleceğini öne sürerek âlemin zamanda yaratıldığına inanırken filozoflar ise Tanrı'nın var olduğu ama âlemin var olmadığı 
bir yokluk döneminin söz konusu olamayacağını savunarak âlemin zaman içinde değil Tanrı'nın ezelî varlığıyla zamansız olduğunu savunur. Her iki tarafın Tanrı ve yaratmaya dair tasavvurlarından kaynaklanan bu yorum farklılığı Gazzâlî (ö. 1111) tarafından iman-küfür tefriki olarak addedilirken ${ }^{1}$ İbn Rüşd (ö. 1198) nezdinde ise terminolojik bir ihtilaf ve salt bir isimlendirme tartışmasından ibarettir.2 Âlemin zamansal olarak Tanrı'dan sonra vücûda geldiğini savunan kelâmcılar tezlerini "hudûs" kavramıyla formüle ederek bu kavramın aynı zamanda kelâmî bir delil olarak şöhret bulmasını da sağlamışlardır. ${ }^{3}$ Bir şeyin daha önce yok iken var olması anlamına gelen hudûs ${ }^{4}$ kavramından kelâmcilar zamansal bir sonralığı anlarken Meşşâî filozoflar ise zâtî veya ontolojik bir hudûsun da mümkün olduğunu savunmuşladır. Başka bir ifadeyle hudûs kavramını sadece kelâmcılar değil âlemin Tanrı tarafından yaratıldığını kabul eden filozoflar da kullanmaktadırlar. Fakat âlemin yaratılması hususunda kelâmcılar, üzerinden bir yokluk süreci geçtikten sonra tüm âlemin zaman içinde yaratıldığını öne sürerek zamansal hudûsu savunurken Meşşâ̂ filozoflar ise âlemi ay üstü ve ay altı şeklinde ayırarak ay üstü âlemin Tanrı tarafından ezelde yaratıldığını savunur ve ay üstü âlemin zaman içinde değil zâtî hudûsla yaratıldığını kabul ederler. ${ }^{5}$ Zâtî hudûs, sadece ontolojik olarak nedenin kendisini sonuca öncelerken, zamansal hudûs nedeni hem ontolojik hem de zamansal olarak sonuca önceler. Âlemin nasıl yaratıldığına bir izah getirme gayreti olarak İslâm düşünce geleneğinde savunulan zamansal ve zâtî hudûs dışında iki hudûs teorisi daha bulunmaktadır. Bunlardan ilki Molla Sadrâ'nın (ö. 1640) hocası Mîr Dâmâd (ö. 1631) tarafından ortaya atılan dehrî hudûs iken diğeri ise Molla Sadrâ'nın hareket-i cevherî teorisine uygun olarak geliştirdiği hudûs görüşüdür.

\section{Kavramsal Çerçeve}

Klasik dönem sonrası İslam felsefesinin en önemli simalarından biri olan Molla Sadrâ'nın hareket-i cevherî teorisine bağlı olarak ele aldığı problemlerden biri de âlemin zaman içinde yaratılıp yaratılmadığı tartışmasına dayanan hudûs-kıdem problemidir. Tanrı'nın âlemi zaman içinde yaratıp yaratmadığı ve âlemle nasıl bir irtibatı olduğunu ortaya koymaya çalışırken bir Tanrı tasavvurunu da izhar ettiğinden meselenin hem ontolojik hem de kozmolojik yönü bulunmaktadır. Bununla birlikte meselenin anahtar kavramı kuşkusuz zamandır. Zira zamandan ve değişimden münezzeh olarak kabul edilen Tanrı'nın sürekli değişen ve zamana tabi olan âlemi nasıl yarattığı meselenin en mühim sorusu olduğu görülmektedir.

\footnotetext{
Gazzâlî, Ebû Hâmid, Tehâfütü'l-felasife, thk: Süleyman Dünya, (Tahran: Şems-i Tebrizî, 1382/2003), 293.

2 İbn Rüşd, Ebü'l-Velîd Muhammed b. Ahmed. Faslu'l-makâl, (Beyrut: Daru'l-Meşrık, 1986), 41.

3 Muhammed Fatih Kılıç, "İbn Sînâ'nın Hudûs Yorumu”, Beytulhikme: An International Journal of Philosophy, 1/2 (2011): 105.

4 Seyyid Şerif Ali b. Muhammed Cürcânî, Kitabu't-Ta'rifât, thk. Muhammed Abdurrahman elMer'aşlî, (Beyrut: Dârü'n-Nefâis, 2003), 145.

5 Hüseyin Atay, Farâbî ve İbn Sinn̂́ya Göre Yaratma, (Ankara: Ankara Üniversitesi İlahiyat Fakültesi Yayınları, 1974, 122-123; Bekir Topaloğlu, "Hudûs", Diyanet İslâm Ansiklopedisi, (İstanbul: TDV Yayınları, 1998), 18: 305-308.
} 
Bilhassa yaratmanın süreklilik arz ettiği İbrahimî dinlerde Tanrı'nın söz konusu yaratma sürecine nasıl müdahil olduğu önemli bir metafizik problem olarak mütalaa edilmiş ve buna dair zaman ve yaratma tasavvurlarıla şekillenen çeşitli teoriler geliştirilmiştir. İslâm düşünce tarihinde kendinden önceki düşünce mirasını harmanlayarak önemli bir senteze ulaşan Molla Sadrâ'nın mezkûr probleme getirdiği çözüm önerisine geçmeden önce İslâm düşünce geleneğinde oldukça canlı bir tartışma zeminine sahip olan meselenin tarihî arka planını netleştirmek için zamansal, zatî ve dehrî hudûsu kısaca izah etmekte yarar var.

\subsection{Zamansal Hudûs}

Âlemin Allah tarafından zamanda yaratıldığı tezine dayanan bu yaklaşım genellikle kelâmcıların hudûs görüşü olarak bilinir. Âlemin yoktan var edildiği inancından hareketle kelâmcılar, âlemin henüz yaratılmadan önce bir zamanın var olduğunu kabul ederler. Bu yaklaşıma göre sadece Allah kadîm olabilir, mâsivâ olarak adlandırılan Allah dışındaki her şey, varlığı yoklukla öncelenmiş anlamında hâdistir. Bir şeyin yokluğunun varlık bulmasından zamansal olarak önce olması, başka bir ifadeyle yokluğunun varlığına mukaddem olması anlamına gelen hudûs kavramıla meseleye yaklaşan kelâmcılar, âlemin varlık nedenini, formüle ettikleri hudûs deliliyle açıklama yoluna giderler. Buna göre her hâdis olanın bir muhdese ihtiyaç duyduğunu, âlem de hâdis olduğuna göre Allah tarafından zamanda yaratıldığ 1 şeklinde bir kıyas yolunu izlerler. ${ }^{6}$ Hudûs kavramının, özünde zamansal bir sonralık taşıdığından hareketle zâtî ve zamansal bir ayrıma gitmeden hudûsu bir şeyin yokluktan sonra var olması şeklindeki yalın anlamıyla kullanırlar.

Âlemin zamansal hudûsla yaratıldığını savunan ilk kelâmcılar cevher ve araz anlayışını esas alarak iddialarını temellendirmeye çalışırlar. Mu'tezilî kelâmcıların geliştirerek kullandığı bu teori, âlemin zamanda yaratılması için ortaya konulan bir yaklaşım olmasının yanı sıra Allah'ın varlığını ispat etmek üzere kullanılan Kelâm Kozmolojik Delili olarak da bilinir. Bu yaklaşıma göre âlemin hâdis olmasının nedeni, varlık bulmak için Tanrı'ya ihtiyaç duymasıdır. Şayet âlem hâdis değil de kadîm olsaydı var olmak için herhangi bir sebebe ihtiyaç duymaz ve böyle bir durumda birden fazla zorunlu varlık söz konusu olurdu. ${ }^{7}$ Örneğin bu yaklaşımın önde gelen kelâmcılarından Bâkıllânî’ye (ö. 1013) göre, âlem özü itibariyle araz olup her araz hâdistir ve var olmak için bir fâile ihtiyaç duyar. Tıpkı yazının bir yazıcıya veya bir binanın bir ustaya ihtiyaç duyması gibi âlemin de bir yaratıcıya ihtiyacı vardır. Dolayısıyla âlemin hâdis olması, âlemin yokken sonradan var olma niteliğinden kaynaklanmaktadır. ${ }^{8}$

Zamansal hudûs teorisinin bir diğer müdafiî olan Gazzâlî ise Meşşâ̂lerin ay-üstü ve ay-altı âlem ayrımı ile sudûr teorisine şiddetle karşı çıkarak Allah dışında semavî küreler dâhil hiçbir varlığın kadîm/ezelî olamayacağını söyler. Gazzâlî,

Topaloğlu, "Hudûs", 305

7 Bekir Topaloğlu, İslâm Kelamcılarma ve Filozoflarına Göre Allah'ın Varlığı (İsbat-ı Vacib), (Ankara: DİB Yayınları,1998), 82 vd; Muhammed Fatih Kılıç, “İbn Sînâ'nın Kelâmcıların Hudûs Görüşüne Yönelttiği Eleştiriler" Divan: Disiplinlerarası Çalışmalar Dergisi, 15/ 28 (2010/1): 117-120.

8 Ebu Bekir el-Bâkıllânî, Kitâbü't-Temhîd, (Beyrut: Dârü'l-Meşrık, 1957), 22-24; Topaloğlu, "Hudûs", 306; Kılıç, “İbn Sînâ'nın Kelâmcıların Hudûs Görüşüne Yönelttiği Eleştiriler”, 118-119. 
âlemin kadîm olduğuna dair filozofların delillerine getirdiği itirazlar üzerinden zamansal hudûsu temellendirmeye çalışır. Gazzâlî̀ye göre Allah âlemden önce var olup âlem zorunlu sebep-sonuç ilişkisiyle değil O'nun iradesiyle yaratılmıştır. ${ }^{9}$ İnsan vehminin öncelik kavramını zorunlu olarak zamansal bir bağlamla kavradığına dikkat çeken Gazzâlî, vehim her ne kadar kabule yanaşmasa da, "âlemin varlığından önce gerçek varlık manasında bir önce yoktur" der. Fakat âlemin yaratılmasından önce Allah'a özgü ezelî bir zamanın da olabileceğine inanır. ${ }^{10}$ Diğer bir ifadeyle, Gazzâlî âlemin yaratılması ile birlikte başlayan ve âlemin yaratılmasından önce ebedî ve tabiatüstü bir zaman olmak üzere iki farklı zamanın var olabileceğini ileri sürer. ${ }^{11}$ Filozofların savunduğu gibi Allah ile âlem arasında bir illet malûl ilişkisinden hâsıl olan zorunlu ve zâtî bir öncelik değil mevhum da olsa zamansal bir öncelik olduğunu savunan Gazzâlî, zamanın âlemle birlikte yaratıldığına ve dolayısıyla âlemden önce gerçek bir zamanın değil, hayalî/vehmî bir zamanın varlığına inandığı görülmektedir. İnsanın kimi kararlarını erteleyebildiğine göre Allah'ın da yaratmaya gücü yetmesine rağmen âlemi yaratmayı murat etmeyip bir süre beklediğini söylerken ${ }^{12}$ Gazzâlî de tıpkı filozoflar gibi Allah'ın ulûhiyetine halel getirmeme çabasındadır. Fakat Gazzâlî’nin bu gerekçesi zatî hudûsu savunan filozoflara tutarlı gelmez.

\subsection{Zâtî Hudûs}

Zâtî hudûs âlemin Tanrı tarafından ezelî bir yaratılışla yaratıldığını, bu anlamda âlemin hâdis olmakla birlikte herhangi bir zaman diliminde yaratılmadığını savunan ve daha çok İslâm filozoflarından İbn Sînâ (ö. 428/1037) ile bilinen bir yaratılış teorisidir. Bu teorinin hakkıyla anlaşılabilmesi için kuşkusuz teoriye zemin kazandıran illiyet ve sudûr anlayışlarından da haberdar olmak gerekir. Aristoteles'in ilk neden/muharrik anlayışının hâkim olduğu Meşşâi varlık anlayışında Tanrı ile âlemin yaratılması arasında illiyet teorisine dayalı bir ilişki vardır. Varlığı zorunlu ve mümkün olmak üzere iki kısma ayıran bu teoriye göre varlığı kendi özünden olan zorunlu varlık dışında tüm varlıklar ancak bir sebeple var olabilen mümkün varlıklardır. Bu anlamda mâsivâ olarak âlemin tümü mümkün olup zorunlu varlık olan Tanrı'ya göre malûldür. Her malûl, illetine göre hâdis olup illeti tarafından öncelenmiştir. ${ }^{13}$ İbn Sînâ'ya göre, kelâmcıların iddia ettiği gibi âlemin varlık sebebi, yokluk tarafından öncelenmesi, yani hudûsu değil, bir sebebe (illet) ihtiyaç duymasıdır. ${ }^{14}$ Bir şeyin sebebe ihtiyaç duyup duymaması sanıldığı gibi zaman içinde yaratıldığı anlamında hudûsla değil imkânla alakalıdır. Başka bir ifadeyle bir şeyin mümkün olup olmaması herhangi bir sebebe ihtiyaç duymadığı anlamına gelmez. Bu bağlamda, İbn Sînâ, "yoklukla öncelenen bir şeyin zaman içinde varlık bulması" olarak tanımlanan hudûsu, zâtî ve zamansal

\footnotetext{
Gazzâlî, Tehâfütü'l-felasife, 80 .

Gazzâlî, Tehâfütü'l-felasife, 96-98.

Oliver Leaman, İslâm Felsefesi: Giriş, trc. Şamil Öçal, (İstanbul: Hece Yayınları, 2014), 48.

Gazzâlî, Tehâfütü'l-felasife, 89-90.

İbn Sînâ, Ebû Alî, et-Ta'likât, thk. Abdurrahman Bedevî, (Beyrut: Mektebü'l-İ'lâmi'l İslâmî, 1404HK), 84-85; a. mlf., eş-Şifâ: el-ilâhiyât, thk. Said Zayed, Kum: Mektebetü Ayetullah el-Merâşî, 1404HK, 167-169; Cüneyt Kaya, Varlık ve İmkân, (İstanbul: Klasik Yayınları, 2011), 233-238.

14 Kılıç, "İbn Sînâ'nın Hudûs Yorumu”, 105.
} 
olmak üzere ikiye ayırmaktadır. Bu ayrıma onu sevk eden illiyet teorisiyle beraber Meşşâi filozofların kozmolojisinin izahı olan sudûr teorisidir.

Âlemin, tabiî olarak Tanrı'dan taşan cömertliğiyle vücuda geldiğini iddia eden sudûr teorisine göre, ay-üstü ve ay-altı olarak ikiye ayrılan âlemin iki tarafında illet-malûl ilişkisi aynı değildir. Semavî akıllar, nefis ve feleklerin bulunduğu ayüstü âlemde illet, hareketten münezzeh olup malûlü için özü gereği varlık veren bir yaratıcı olduğundan malûlünden zamansal olarak değil zâtî/ontolojik olarak öncedir. Ay-üstü âlemde illet-malûl ilişkisi illetin malûlünü gerektirdiği bir birliktelik (mâ̂̀yyet) ilişkisidir. Çünkü illet var oldukça malul de var olmak durumundadır. ${ }^{15}$ Ay-üstü âlemde ontolojik bir zorunluluktan kaynaklanan illet ile malûl arasındaki ilişkide yaratma aracısız ve zâtî olarak meydana geldiğinden zamansal bir hudûs söz konusu olamaz. Bu yaratmayı doğrudan ve zamansız yaratma anlamında $i b d a^{\prime}$ ile ifade eden İbn Sînâ'ya göre semavî varlıkların imkânı, varlıklarından önce değil varlıklarıyla beraber olduğundan dolayı varlık kazanmaları herhangi bir maddenin aracılığıyla ve zaman içinde gerçekleşmez. ${ }^{16}$ Dolayısıyla bu yaratmada ne illet ne de malûl tarafında kuvveden fiile çıkma olarak tarif edilen herhangi bir hareket ve değişim olmadığından, hareketin sayısı/ölçüsü olan zamandan söz edilemez.

İbn Sînâ, illetin malûlden zâtî önceliğini meşhur el ve anahtar teşbihiyle izah etmeye çalışır. Buna göre el ile anahtar aynı anda hareket etse de anahtara hareket veren el olduğundan elin hareketi zâtî olarak anahtarın hareketinden öncedir. ${ }^{17}$ Aynı zamanda güneş ile ışı̆̆ı arasındaki ilişki üzerinden de zâtî hudûsu izah etmeye çalışan İbn Sînâ'ya göre ışık güneşten bağımsız bulunamadığı gibi güneşin var olduğu fakat ışığının olmadığı bir zaman dilimi düşünülemez. Bu nedenle güneşin, 1şığıyla olan ilişkisi bir illet-malûl ilişkisi olup güneş, ışığıyla zamanda beraberken zâtî/ontolojik anlamda sonradır. ${ }^{18}$ Zâtî hudûsa göre tıpkı güneş ve işı̆̆ ilişkisinde olduğu gibi Tanrı ile âlem arasında bir zorunlu beraberlik durumu bulunmaktadır. Aksi durumda, âlem şayet zamanda yaratılmış olsaydı Tanrı'nın var olduğu ama âlemin var olmadığı bir yokluk dönemi söz konusu olurdu. Ne var ki böyle bir durum Tanrı'nın başta yaratıcı olmak üzere birçok sıfatının bu yokluk döneminde âtıl kalması veya bu sıfatlarını sonradan kazanması gibi teolojik bir tutarsızlığa yol açacak ve Tanrı'nın varlığıyla ezelî ve ebedî olan sıfatlarına halel getirecektir. ${ }^{19} \mathrm{Bu}$ nedenle Tanrı, âlemin sebebi olarak zâtî veya ontolojik bir

15 İbn Sînâ, eş-Şifâ: el-ilâhiyât, 163-169; Kılıç, İbn Sînâ'nın Hudûs Yorumu, 105-106.

16 İbn Sînâ, eş-Şifâ: el-îlâhiyât, 266-268; Atay, Farâbî ve İbn Sînâ'ya Göre Yaratma, 140, Atay, semavî varlıkların geçmişlerinde bir imkân bulunmaması sebebiyle İbn Sînâ tarafından yetkin olarak ibda' ile yaratıldıklarını yorumlarken yetkinlik düzeyi anlamında semavî varlıkların Tanrı'dan daha aşağı olduklarına dikkat çeker. Aksi takdirde kelamcıların zamansal hudûsu savunurken uzak durmaya çalıştıkları ezelî varlıkların sayısı artacaktır.

17 İbn Sînâ, eş-Şifâ: el-illâhiyât, 165; a. mlf., el-İ̧sârât ve't-tenbîhât, (Nasıruddin et-Tûsî'nin Şerhli Metni) (Kum: Neşrü'l-Belağe, 1375/1996), 106.

18 Murtaza Mutahharî, Felsefe Dersleri 1, trc. Ahmet Çelik, (İstanbul: İnsan Yayınları, 1997), 353-354.

19 İbn Sînâ, Ebû Alî, el-Mebde' ve'l-me’âd, tsh. A. Nûrânî, (Tahran: Müessese-i Mütâla'ât-i İslâmî, 1363/1984), 46; a. mlf. eş-Şifâ: el-ilâhiyât, 380; Ayrıca bk. Atay, Fârâbî ve İbn Sînâ'ya Göre Yaratma, 142143; Kılıç, “İbn Sînâ'nın Kelâmcıların Hudûs Görüşüne Yönelttiği Eleştiriler”, 131-132. 
takaddüm ile âlemden önce olup âlem Tanrı'nın varlığıyla doğrudan ve zamansız olarak yaratılmıştır.

Hudûsun hem zâtî hem de zamansal olabileceğini söyleyen İbn Sînâ, oluş ve bozuluşa konu olan ay-altı âlemin zamansal bir hudûsla yaratıldığını söyler. Zâtî hudûsta illet, malûlünden sadece zat itibariyle önce iken zamansal hudûsta illet malûlünden hem zat hem de zamansal olarak öncedir. Başka bir ifadeyle ay-altı âlemdeki varlıklar, içinde bulunmadıkları bir zaman ile mesbukturlar. ${ }^{20}$ Sudûr teorisine göre ay-üstü âlemde yer alan feleklerin hareketiyle Faal Akıl ay-altı âleme varlık bahşeder. $\mathrm{Bu}$ yaratmada ay-altı âlemdeki varlıkların varlık bulması kuvveden fiile çıkma biçiminde olduğundan maddenin aracılığıyla, dolayısıyla zamansal bir hudûsla gerçekleşmektedir. Bu anlamda zâtî hudûs ile zamansal hudûs arasındaki yaratılış şeklini $i b d a^{\prime}$ ve $h u d \hat{u}$ k kavramlarıyla ayırt eden İbn Sînâ aynı zamanda ay-üstü ve ay-altı olarak ayırdığı varlık kategorilerindeki illet ile malûl arasındaki zamansal ilişkinin farklılığını kavramsal olarak da ifade eder. Buna göre ezelî olan Tanrı ile zâtî hudûsla vücuda gelen ay-üstü âlem arasındaki ilişki sermedî bir ilişki iken, ay-üstü âlem ile ay-altı âlemdeki zamanlı varlıklar arasındaki ilişki dehrî, ay-altı âlemdeki zamanlı varlıkların kendi aralarındaki ilişki ise zaman̂̂ bir ilişkidir. ${ }^{21}$ İbn Sînâ'nın âlemi ay-üstü ve ay-altı şeklinde kategorik bir ayrımla bölerek ay-üstü âlemdeki varlıkları ezelde Tanrı ile beraber ve yetkin görmesi, her ne kadar Tanrı'nın yetkinliği ile aynı görmese de, başta Gazzâlî olmak üzere kendinden sonraki birçok kimse tarafından eleştirilmiştir. Nitekim Mîr Dâmâd'ın dehrî hudûs ve Molla Sadrâ'nın cevherî harekete dayalı hudûs teorilerinde de bu minvalde yapılan eleştiriler göze çarpmaktadır.

\subsection{Dehrî Hudûs}

Zamansal hudûs ile zâtî hudûsun söz konusu problemi çözemediklerini iddia eden Mîr Dâmâd, önceki yaklaşımlara getirdiği eleştiriler üzerinden şekillenen bir kozmogoni tasavvuruyla problemi ele alır. $\mathrm{O}$, yokluktan sonra meydana geldiği iddia edilen varlık ile yokluk arasındaki zaman farklılığı nedeniyle yokluğu ortadan kaldırmadığı, yanı sıra Tanrı'nın ezelî cömertliğinin cari olmadığı bir zaman tasavvuru öngördüğü gerekçesiyle zamansal hudûsa eleştiriler getirir. ${ }^{22}$ İbn Sînâ'nın savunduğu zâtî hudûsun kategorik âlem anlayışından etkilenmekle beraber yaklaşımın felsefî bir temele dayanmadığını ve özellikle İbn Sînâ'nın sermed ve dehr kategorilerine yerleştirdiği varlıkların yekdiğeriyle ilişkisi konusunda muğlak bir alg1 oluşturduğunu iddia eder. ${ }^{23}$ Mîr Dâmâd'ın bütün çabası, Fazlurrahman'ın (ö. 1988) da ifadesiyle, Tanrı ile mümkün varlıklar arasında tamamen lâfzî ve zihnî bir ayırım içinde buharlaşma tehdidiyle karşı karşıya kalan zâtî hudûsu yorumlayarak dehr veya sonsuz zaman mertebesinde

20 İbn Sînâ, el-İsârât ve't-tenbîhât, 106.

21 Mehmet Nesim Doru, “Mîr Dâmâd'ın Hudûs Konusunda İbn Sînâ'ya Yönelttiği Eleştiriler ve Hudûs-u Dehrî Görüşü", Felsefe Dünyası, 56 (2012/2), 258-259.

22 Doru, "Mir Dâmâd'ın Hudûs Konusunda İbn Sînâ'ya Yönelttiği Eleştiriler ve Hudûs-1 Dehrî Görüşü", 263.

23 Mir Dâmâd, el-Kabasât, thk. Mehdi Muhakkik vd, (Tahran: İntişârât-1 Danişgâh-1 Tahran, 1367), 8-9. 
gerçekleşen daha gerçekçi bir hudûsun imkânını temellendirmeye çalışmaktır. ${ }^{24}$ Belki onu bu çabaya iten asıl saik ise tüm nitelikleriyle sonsuz bir makama yerleştirdiği Tanrı ile yarattığı âlemi, zamansal düzeyde de olsa, aynı kategoriye koymaktan imtina etmesi olduğu söylenebilir.

İbn Sînâ'nın ezelî olarak kabul ettiği Tanrı ile akıllar ve semavî küreler arasındaki ilişkiyi bazen sermed bazen de dehr kavramyla ifade ederek bu ilişkiyi zihnî boyuta indirgemesi onu, ontolojisinde zorunlu ile mümkün arasına çektiği keskin çizgiden uzaklaştırmıştır. ${ }^{25}$ İbn Sînâ'nın her ne kadar zorunlu ile mümkün arasındaki büyük uçurumu kapatmak için böyle bir şey yaptığı iddia edilse de $^{26}$ bu durumu Tanrı ile âlem arasındaki ayrımın buharlaşmasına bir tehdit olarak gören Mîr Dâmâd'a göre, mutlak anlamda sonsuz olan Tanrı'nın zaman ve mekânın yaratıcısı olarak hiçbir varlıkla zamansal bir beraberliği olamaz. Sermed makamında bulunan Tanrı'nın imkân âlemiyle olan beraberliği zamansal ve mekânsal bir beraberlik değil ölçülemeyen bir kuşatma ilişkisidir. ${ }^{27}$ Zamansal varlık kategorilerinden sermed ile dehr'i İbn Sînâ'nın aksine net bir şekilde birbirinden ayıran Mîr Dâmâd'a göre sermed makamı her türlü zaman ve mekândan münezzeh olan Tanrı'ya aittir. Tanrı'dan açık bir ayrışma veya kopuşla (infikakî) yaratılan imkân âlemi ise Tanrı'ya nispetle dehr boyutundadır. ${ }^{28}$ Sermed boyutunda ibdâ ve tekvinin sahibi olan yalnızca Tanrı'dır. Akılların ve semavî kürelerin ne zamansal bir beraberlikle ne de illet ve malûl ilişkisine dayalı bir sonralıkla sermed boyutunda yer alması mümkündür. Malulün illetiyle aynı varlık mertebesinde olamayacağını söyleyen Dâmâd'â göre illet-malûl ilişkisi sermed boyutunda değil dehr'de gerçekleştir.29 Bu nedenle der, Mîr Dâmâd, sermedî bir önceliğe sahip olan Tanrı ile âlem arasında sarih bir yokluk dikkate alındığında âlemin yaratılmasının dehrî hudûs olarak adlandırılması daha doğru ve daha münasiptir. ${ }^{30}$

Gerek zamansal hudûsta gerekse zatî hudûsta "zamanda yaratma" anlaminda kullanılan hudûsun yanlış kullanıldığına dikkat çeken Mir Dâmâd'a göre şayet Allah'ın kâinat veya ilk varlıkları bir zamanda yarattığı söylenirse o halde bu zamandan önce ne kadar zaman geçtiği sorusu akla gelecektir. Oysa Allah zamandan münezzeh olduğu için bu soruya verilebilecek en mantıklı cevap ilk yaratmadan önce zamanın bulunmadığıdır. Şu halde ilk yaratılan varlığa kadar hiç zaman geçmedi ise o varlığın yaratılması da zaman içinde değildir. Dolayısıyla ilk

24 Fazlurrahman, “Mîr Dâmâd'ın Hudûs-i Dehrî Kavramı: Safeviler Dönemi İran'da Tanrı-Âlem İlişkisi İle İlgili Çalışmalara Bir Katkı", trc. M. Nesim Doru, İstanbul Üniversitesi İlahiyat Fakültesi Dergisi, 27 (2012): 234.

25 Fazlurrahman, “Mîr Dâmâd'ın Hudûs-i Dehrî Kavramı: Safeviler Dönemi İran'da Tanr1-Âlem İlişkisi İle İlgili Çalışmalara Bir Katkı", 234; Doru, "Mîr Dâmâd'ın Hudûs Konusunda İbn Sînâ'ya Yönelttiği Eleştiriler ve Hudûs-u Dehrî Görüşü", 261.

26 Atay, Farâbî ve İbn Sinnâya Göre Yaratma, 122.

27 Mir Dâmâd, Kabasât, 123; a.mlf., el-İmazât, Musannefât-ı Mîr Dâmâd içinde, thk: Abdullah Nurânî, (Tahran: İntişârât-1 Encümen-1 Asâr ve Mefâhir-1 Ferheng, 1381/2002), 13-14

28 Mir Dâmâd, Kabasât, 25-26; a.mlf., İmazât, 5; Doru, "Mir Dâmâd'ın Hudûs Konusunda İ̉n Sînâ'ya Yönelttiği Eleştiriler ve Hudûs-1 Dehrî Görüşü", 262.

29 Mir Dâmâd, Kabasât, 75.

30 Mir Dâmâd, Kabasât, 7. 
yaratmanın geçmiş, şimdi ve gelecek gibi boyutları olmayan ve saf zaman anlamına gelen dehr kavramiyla ifade edilmesi gerekir. ${ }^{31}$

İbn Sînâ'nın ay-üstü ve ay-altı âlem ayrımını kabul etmeyen ve âlemin bir bütün olarak tek aşamada açık bir yokluktan sonra yaratıldığını savunan Dâmâd, varlıkların ontolojik konumunu ve aralarındaki dinamik ilişkiyi belirtmek için ise benzer bir ayrıma gitme ihtiyacı hisseder. Mîr Dâmâd'ın anlaşılması kolay olmayan hudûs yaklaşımında son derece önem arz eden bu ayrım üçlü bir kategori halinde sermed, dehr ve zaman kavramları ile ifade edilir. İbn Sînâ'nın varlık kategorileri arasındaki zamansal ilişkiyi ifade etmek için kullandığı bu kavramlara Mîr Dâmâd ayrıca her biri belirli bir varlık türünün muayyen ontolojik mekânını temsil eden üç farklı boyut anlamını da katmaktadır. Bu üçlü taksimde ezelîlik makamını temsil eden sermed, saf varlığın (mutlak veya teolojik olarak Tanrı) metafizik boyutudur. Zaman-üstü alanla ilgili olan dehr ise maddî olmayan semavî akıllar ve sabit kürelerin alanını temsil eder. Zaman'a gelince oluş ve bozuluşla değişen seyyal varlıkların fizikî boyutudur. ${ }^{32}$

Dâmâd'a göre Tanrı ile âlem arasında illet ve malûl ilişkisi olsa da filozofların sandığı gibi ibda' yoluyla yaratılan varlıklar ile Tanrı arasında zamansal bir beraberlik mümkün değildir. Bu varlıkların var oluşu dehr boyutunda dehrî bir öncelikle salt yokluk tarafından öncelenmiştir. ${ }^{33}$ Hudûs yaklaşımında kilit bir role sahip olan dehr kavramıla ilgili Dâmâd'ın "dehr, zamanın kabıdır, çünkü onu kapsar" 34 "dehr, zamanla beraberdir (fakat zaman değildir). Nasil ki sermed dehr'den daha yüce, mukaddes ve genişse dehr de zamandan daha yüce ve daha geniştir"35 şeklindeki ifadelerine topluca baktığımızda dehri, zamanı da kapsamakla birlikte oluş ve bozuluş âleminin hareketinden ve fizikî zamanından azade olan fakat ezelî olmayan bir tür zamansızlık boyutu anlamında kullandığını söyleyebiliriz. Bu anlamıyla Dâmâd dehri, tıpkı İbn Sînâ'nın kullandığı anlamıyla değişim ve dönüşüm uğramayan semavî kürelerin tâbi olduğu zaman kategorisi olarak kullanmakla birlikte sonsuz zaman anlamına gelen fakat Tanrı'nın ezelîliğine münhasır daha yüce bir makamı ifade eden sermed kategorisinden ayrı, ontolojik ve metafizik bir mekân olarak nitelediği görülmektedir. Nitekim Mîr Dâmâd'ın dehr görüşünü yorumlayan Fazlurrahman dehri, zamanın uzamı olmaksızın yaratma veya 'imkân'ın var olduğu 'salt zaman' âlemi olarak yorumlarken ${ }^{36}$ Izutsu ise dehri, zaman üstülük ve maddi olmayan bütün varlıkların metafizik boyutu olarak tanımlar. ${ }^{37}$

31 Fazlurrahman, “Mîr Dâmâd'ın Hudûs-i Dehrî Kavramı: Safeviler Dönemi İran'da Tanrı-Âlem İlişkisi İle İlgili Çalışmalara Bir Katkı”, 235; Alparslan Açıkgenç, "İslâm Düşüncesinde Zaman Anlayışının Felsefî Tahlili" Uluslararası İslâm Medeniyetinde Zaman Sempozyumu, (Konya: 2015), 26.

32 Toshihiko Izutsu, "Mîr Dâmâd ve Metafiziği" trc. M. Nesim Doru, Eskiyeni, 30 (Bahar 2015): 177178.

33 Mir Dâmâd, İmâzât, 3-4.

34 Mir Dâmâd, Kabasât, 8.

35 Mir Dâmâd, Kabasât, 5.

36 Fazlurrahman, "Mîr Dâmâd'ın Hudûs-i Dehrî Kavramı: Safeviler Dönemi İran'da Tanrı-Âlem İlişkisi İle İlgili Çalışmalara Bir Katkı", 235.

37 Izutsu, "Mîr Dâmâd ve Metafiziği", 178. 
Sermed ile dehr boyutlarını ayırmada Dâmâd'ın, Tanrı ile âlem arasına ontolojik anlamda kesin bir ayrım koyma niyeti ve kaygısı net bir biçimde göze çarpmaktadır. Felsefesinin genel bir özelliği haline gelen bu maksudundan hareketle dehr âleminin öncesinde zaman üstü bir yokluk arayan Dâmâd, âlemin bu yoklukla açı bir biçimde ayrılarak/koparak yaratıldığını savunur. ${ }^{38}$ Dehrî hudûsu, zâtî hudûstan olduğu kadar zamansal hudûstan da ayıran bu yaklaşımın özü, zamansal bir uzamın olmadığı dehr boyutunda açık bir yokluk tarafından öncelenen âlemin bir bütün olarak var edildiği esasına dayanır. Dehr ve zaman boyutunda varlık bulan varlıkların hudûsunda 'varlıktan önce açık bir yokluk' görüşü Dâmad'ın varlık kategorileri arasındaki hiyerarşiyi de tayin etmektedir. Zira Dâmâd'a göre her bir varlık mertebesi sonraki mertebenin sebebidir. Başka bir ifadeyle her varlık mertebesi bir üst mertebesinde yer alan yokluğun vücut bulmuş halidir. Dolayısıyla zamansal âlem dehr âleminde, dehr âlemi ise sermed âleminde mevcut değildir. ${ }^{39}$ Tanrı ile imkân âlemi arasındaki ontolojik ayrımın zâtî hudûs ile müphem hale geldiğini savunan Mîr Dâmâd, dehrî hudûsla âlemdeki varlıkları kategorik bir ayrıma tabi tutarak aralarındaki ontolojik ayrımı daha mütemayiz kıldığını ve hudûs problemini çözdügünü düşünüyordu. Fakat onun parlak öğrencisi Molla Sadrâ, hocasının hudûs görüşünü tatmin edici bulmayacak ve cevherî hareket teorisine mutabık bir çözüm önerisi ortaya atacaktı.

\section{Molla Sadrâ'nın Hudûs Yorumu}

Önceki hudûs yaklaşımlarından yola çıkarak problemi ele alan Molla Sadrâ, problemin çözümünde zaman kavramının önemine dikkat çeker. Varlı̆̆ın özünde taşıdığ1 cevval ve yatışmaz hareketin ölçüsü olarak tanımladığı zamanın, âlemin hareketiyle başladığını dolayısıyla âlemin zamansal bir hudûsla her an yeniden yaratıldığını belirtir. Fakat Sadrâ, zamansal hudûsla kelâmcıların savunduğu anlamda üzerinde zamansal yokluğun geçtiği bir hudûsu kastetmediğini israrla vurgulayarak âlemin yaratılmasına zamansal bir yokluğu mukaddem gören yaklaşımın vahyin öğretilerinden uzak olduğu gibi sağlam bir aklî delilden de yoksun olduğunu söyler. ${ }^{40}$ Sadrâ önceki hudûs yaklaşımlarını değerlendirirken hem kelâmcıların hem de filozofların zamanın hakikatini kavrayamadıklarından dolayı bu girift meselede hudûsu yanlış yorumladıklarını iddia eder. ${ }^{41}$

Evvela kelamcıların âlemin yaratılışından önce varsaydıkları zamanın hareketle olan zorunlu beraberliğine işaret eden Sadrâ'ya göre varlık ile hareket ve zaman arasında bir illiyet (nedensellik) olsa da bu illiyet, illetin malûlünden zamansal olarak önce geldiği türden bir illiyet değil, zâtî bir illiyettir. Çünkü her zamandan

38 Doru, "Mir Dâmâd'ın Hudûs Konusunda İbn Sînâ'ya Yönelttiği Eleştiriler" ve Hudûs-1 Dehrî Görüşü", 268.

39 Doru, "Mir Dâmâd'ın Hudûs Konusunda İbn Sînâ'ya Yönelttiği Eleştiriler ve Hudûs-ı Dehrî Görüşü", 269.

40 Molla Sadrâ, Sadrüddîn Muhammed b. İbrâhîm b. Yahya Kavâmî Şîrâzî, el-Hikmetu'l-müteâliye fi esfâri'l-aklîyyeti'l-erbaâ, (Beyrut: Dar-1 Ehya-ut-Turas, 1981), I: 25, VII: 328-329, (Adı geçen eser kısaca Esfâr olarak bilindiğinden biz de bundan sonra bu adla zikredeceğiz); a.mlf., Risaletu fi'l-hudûs, thk. Seyyid Hüseyin Museviyân, (Tahran: Bunyad-1 Hikmet-i İslâmî, 1378/1999), 15-16, 27.

41 Molla Sadrâ, Esfâr, III: 148-152; a. mlf., Risaletu fi'l-hudûs, 16-17. 
önce bir zaman ve her hareketten önce gelen bir hareket vardır. ${ }^{42}$ Bir şeyin illetinin o şeyin zatından ayrı olması gerekir fakat bu ayrılık zamansal bir öncelik anlamında değildir. Allah'ın zamandan önceliğini Sadrâ, Allah-âlem münasebetiyle ilişkilendirerek lambanın ışığa veya kâtibin yazıya nispetle önceliğine benzetir. ${ }^{43}$ Sadrâ'ya göre zaman için bir başlangıç anı farz edildiğinde bu anın başka bir zamanla mesbuk olması gerekir ve bu durum zamanın başlangıcı için tayin edilen her an için geçerlidir. $O$ halde zaman için mutlak bir başlangıç/bidayet ve son/nihayet yoktur. Bu sebepten olacak ki, der Sadrâ, felsefe muallimleri, zamanın hâdis olduğuna inanan kimseler farkında olmadan zamanın kadîm olduğuna inanmaktadırlar. ${ }^{44}$ Zaman için, tıpkı hareket-i cevherîde olduğu gibi bir limitin (tarf) var olmasının muhal olduğuna vurgu yapan Sadrâ'ya göre zaman için muayyen bir başlangıç ve bitiş anı tayin edilemez. Bu nedenle zamanın olmadığı bir yokluk anının varolduğunu öne sürerek zamanın da hâdis olduğunu savunan kelâmcıların görüşlerini teselsüle veya kısırdöngüye yol açacağı gerekçesiyle reddeder. ${ }^{45}$

Hudûsun ne zaman başladığını sorgulamak için zamandan ne kadar geriye gidilirse Allah'ın hudûs halinde olduğunun müşahede edileceğini savunan Sadrâ, her zamandan önce bir zamanın var olduğu tezini âleme varlık bahşeden ilahî feyzin ezelîliği ve kesintisizliğine dayandırmaktadır. İlahî feyz ve cömertliğin kesintisizliği ile kudretin ezelîliğinden hareketle yaratılışın da muayyen bir başlangıcının olmadığını söyleyen filozofumuz, ilahî feyzi maddenin cevval hareketinin sebebi olarak gördüğünden ne yaratılış için ne de zaman için bir başlangıç noktası tayin etmenin mümkün olduğunu ifade eder. ${ }^{46}$ Bu nedenle Sadrâ, kendi hudûs anlayışını zamansal hudûs olarak adlandırsa da onun hudûs anlayışı, âlemin yaratılışının öncesinde zamanın varlığını kabul eden ve böyle bir zamanın belli bir noktasında âlemin yaratıldığını öngören kelâmcıların zamansal hudûsundan farklıdır. Çünkü ona göre zaman, âlemin dinamik yapısından hâsıl olan bir kavram ve varlığın bir boyutu olduğundan âlemin yaratılmasından önce kelâmcıların iddia ettiği gibi mevhum veya boş bir zamanın varlı̆̆ı söz konusu olamaz.

Zatî hudûs hakkında ise Sadrâ Allah'ın yaratma sıfatının ve ilahi feyzinin ezeli olduğu hususunda Meşşâi filozoflarla hemfikir olsa da zamansız/zaman üstü bir yaratma anlamındaki zatî hudûsu ve âlemin kıdemini kabul etmez. Çünkü âlem olarak tasvir edilen alanda bulunan tüm varlıklar hareket ve seyelan halinde olduklarından zamansal bir hudûsla her an yeniden yaratılmaktadırlar. ${ }^{47}$ Âlemde bulunan hiç bir varlık zamanın olmadığı bir anda yaratılmış olamaz diyerek âlemin kapsamını oluş ve bozuluşa tabi olan cismânî varlıklarla münhasır gören Sadrâ'ya göre Allah'ın esmasının suretleri olan ayrık (mufarık) suretler, mâsivâya

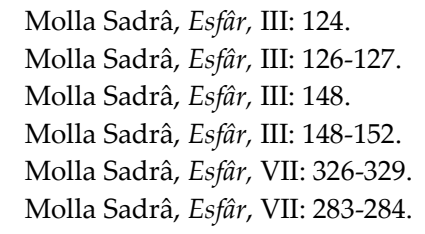


ve dolayısıyla âlemin kapsamına alınamaz. ${ }^{48}$ Âlem bir bütün olarak hareket ve zamana tâbi olan ve cismanî varlıkların tümünü kapsayan bir alan olup tüm zerreleriyle her an yeniden yaratılan ve zaman mecrasında vukû bulan bir hudûs halindedir. Buradan hareketle Sadrâ Meşşâî filozofların âlemi ay-üstü ve ay-altı olarak bölerek ay-üstü âlemi kadim olarak görmelerine ve buna bağlı olarak hudûsu da zamansal ve zatî olarak ayırmalarına karşı çıkar. Sadrâ'nın varlık anlayışında maddî ve cismanî varlıkların tümü "fakr" dediği ontolojik bir gereksinim ve bağımlılıkla varlığın membaina muhtaç ve bağlıdırlar. Bu ihtiyaç ve bağlılık sadece yaratılış anıyla sınırlı değil, süreklilik arz eden bir bağlılıktır. ${ }^{49}$ Fakat Sadrâ hudûsun hareket ve zamanla olan ayrılmaz beraberliğini savunduğundan Allah'ın zatından ayrı bir varlığa sahip olmayan mufarık akılların maddeden mücerret olduklarını, dolayısıyla hareket ve zamandan da azade olup hudûs ile yaratılmadıklarını savunur.

Âlemin kıdemini savunmanın Kur'ân'a ve şeriate de muhalif olduğunu söyleyen Sadrâ'ya göre istikrar makamı olan ilâhî alanın dışında kalan masivâdan hiçbir varlık kadîm olamaz. Ona göre yerde, gökte ve ikisi arasında bulunan tüm varlıkların hudûsu zamansaldır. Çünkü cevherlerinde taşıdıkları hareketle sürekli bir yenilenme halindedirler. ${ }^{50} \mathrm{Bu}$ nedenle cismanî cevher varlığ $\breve{1}$ ve devamlılığ 1 bakımından kadîm olmak şöyle dursun tıpkı değişen, dönüşen ve her sonraki anı önceki anından farklı olan zaman gibidir. Güneş ve ay dâhil tüm gök cisimleri de âlemin kapsamında olup değişip dönüşmede tıpkı yeryüzünde Zeyd ve Amr gibidir. Ne şahıs ne de tür olarak hiçbiri için ezelî bir kıdem ve sermedî bir sonsuzluk söz konusu olamaz. ${ }^{51}$

Mîr Dâmâd'ın dehrî hudûs görüşüne gelince Sadrâ'nın hocasının görüşlerini açık bir biçimde hedef almaktan kaçındığı görülmektedir. Sadrâ'nın bu konuda hocasına duyduğu saygıdan dolayı tevakkuf ettiği gibi görülse de $^{52}$ âlem tasavvuru ve cevherî hareket anlayışına bağlı olarak ortaya koyduğu zaman ve hudûs anlayışından hareketle hocasıyla hemfikir olmadığını rahatlıkla söyleyebiliriz. Zira hudûsun sadece hareket ve zamana tâbî olan cismanî varlıklar için vakî olduğunu savunan Sadrâ için sermed, dehr ve zaman şeklinde âlemi ontolojik bir konumlandırmayla ayıran dehrî hudûs ile âlemi ay-üstü ve ay-altı olarak ayıran zatî hudûsun farkı yoktur. Sadrâ'nın önceki hudûs yaklaşımlarına getirdiği eleştiriler cevherî hareket teorisine uygun olarak kendi hudûs görüşünü ortaya koyarken daha net görülebilecektir.

Felsefesinin genel karakteristiğine uygun olarak Sadrâ hudûs probleminde kendinden önceki İslâm düşünürlerinin görüşlerini vahyin öğretileriyle beraber değerlendirmeye çalışır. Kur'ân'dan getirdiği birçok ayetin zamansal hudûsa işaret

48 Molla Sadrâ, Esfâr, VI: 315; a. mlf., Mefâtihu'l-gayb, thk. Muhammed Hacevî, (Tahran: Müessese-i Tahkikât-1 Ferhengî, 1363/1984), 396; a.mlf., Risaletu fi'l-hudîs, 5.

49 Molla Sadrâ, Esfâr, I: 218-219, 233-234.

50 Molla Sadrâ, Risaletu fi'l-hudûs, 110-112.

51 Molla Sadrâ, Mefâtihu'l-gayb, 397; a. mlf., Risaletu fi'l-hudûs, 15.

52 Gholam Huseyin İbrahim Dinanî, Muamma-yı Zaman ve Hudûs-ı Cihân, (Tahran: Muessese-1 Pijuheşi-i Hikmet ve Felsefe-i İran, 2014), 419. 
ettiğini söyleyerek hikmetin şeriate muhalif olamayacağını sıklıkla dile getirir. ${ }^{53}$ Sadrâ hudûsun bir iman meselesi olduğunu, bu nedenle körü körüne kabul etmek yerine rasyonel bir zemine oturtulması gerektiğini söyler. ${ }^{54} \mathrm{Bu}$ amaçla özgün teorisi cevherî hareketten yola çıkarak savunduğu zamansal hudûs için rasyonel bir zemin tesis etmeye çalışır. Cevherî hareket teorisine göre âlem cevheri itibariyle devamlı surette hareket halinde olup, zaman bu cevherî hareketin sayısıdır. Dolayısıyla âlemin var olmadığı bir hareket hali ve hareketin olmadığı bir zaman/an söz konusu olamaz. Bu nedenle "âlem ne zaman yaratıldı?" sorusu anlamsız bir sorudur. Zira Newton'un mutlak zaman anlayışının aksine âlemin dışında bağımsız olarak akan bir zaman yoktur. Zaman, her an yenilenmekte olan âlemin/maddenin hareketinden soyutlanan zihnî bir kavram ${ }^{55}$ olduğuna göre âlemin yaratılış zamanını sorgulamak veya ona bir başlangıç anı tayin etmeye çalışmak beyhude bir çabadır. ${ }^{56}$ Âlemi çevreleyen ve âlemin dışında var olan bir zamandan bahsedemeyiz fakat âlem her zerresiyle her an yenilenmekte olduğundan bu yenilenmeyle âlemin her cüzü hudûs halindedir. Mütemadi bir hareketle hudûs ve zeval halinde olan maddî cisimlerden müteşekkil cismanî âlemin bütünü, parçalarının tâbi olduğu koşullara bağlı olarak cevherî bir harekete tâbi olup her an yaratılmakta/yenilenmektedir. ${ }^{57}$

Sadrâ'ya göre yenilenme her varlığın özsel niteliklerinden olup söz konusu varlığın an be an yenilenmesi zaman yatağında ve o varlığın cevherinde vukû bulmaktadır. İşte bu nedenle bu hudûsa 'zamansal hudûs' denilmelidir. Buna göre bütün tâbiî varlıkların cevherleri her an hudûs halindedir. Tabiat âlemi de her an değişim (tebeddül) ve akış (seyelan) halinde yenilenen cüzlerinin toplamından başka

53 Molla Sadrâ, Esfâr, VII: 326. Birçok eserinde şu ayetleri âlemde zamansal hudûsun varlığına delil olarak getirir: "Gökleri, yeri ve aralarındakileri altı günde yaratan O'dur." Furkan 25/59; "O, her an yeni bir yaratmadadır." Rahman 55/29; "Dă̆ları görürsün, onları hareketsiz sanırsın. Hâlbuki onlar bulutlarm geçişi gibi hareket ederler." Neml 27/88; "Hayır, onlar yeni bir yaratma hususunda şüphe içindedirler." Kâf, 50/15; "Sizin yerinize benzerlerinizi getirelim ve sizi, bilmediğiniz bir biçimde yeniden inşa' edelim." Vakı'a 56/61. Molla Sadrâ, Esfâr, III: 110; a.mlf., Risaletu fi'l-hudûs, 59-60.

54 Molla Sadrâ, Hudûsu'l-âlem, 182.

55 Zihnî varlık, kavram olarak felsefede bir varlığın insan bilincinden bağımsız dış âlemde var olmasına tekabül eden aynî/haricî varlığa karşıt olarak dış dünyada nesnel bir gerçekliği bulunmayıp sadece insan bilincinde tasavvur edilen varlıklar için kullanılan bir kavramdır. Sadrâ eşyanın kavram ve gerçekliği arasındaki ayrıma dayanan aynî-zihnî ayrımı konusunda zihnî varlığın da aynî varlıktan soyutlanan (intizâ̂) bir varlığı olduğunu söyler. Sadrâ'ya göre varlık dış âlemde tek bir hüviyete sahiptir. Fakat eşyanın insan zihninden bağımsız ve nesnel olan haricî/aynî varlığının husûlî bilgilerle veya kavramsal analiz yoluyla zihinde vücuda gelen ve sübjektif olan başka bir varlığı vardır. Zihnî veya ilmî varlık dediği bu varlık, eşyanın aynî varlığının zihin tarafından tasavvur edilmesiyle hâsıl olmaktadır. Fakat zihnî varlık soyutlandığı aynî varlığın hakikatinden farklı bir varlığa sahip olmayıp aynı varlığın iki farklı bakış açısından görülen yegâne gerçekliğidir. Sadrâ'ya göre soyutlanan zihnî varlığın (el-vücûdu'l-intizâî) gerçek varlıkla (elvücûdu'l-hakîkî) olan ilişkisi "insanlık" In bir insanla olan ilişkisi gibidir. Molla Sadrâ, Esfâr, I: 255; a. mlf., et-Tasavour ve't-Tasdik, (Kum: İntişârât-1 Bidar, 1371/1992), 1-6.

56 Abdülkerim Surûş, Evrenin Yatışmaz Yapısı, trc. Hüseyin Hatemi, (İstanbul: İnsan Yayınları, 2008), 91-93.

57 Molla Sadrâ, Esfâr, VII: 297. 
bir şey olmadığına göre o halde tabiat âlemi her lahza zamansal hudûsla yenilenmektedir. ${ }^{58}$

Sadrâ'nın hudûs yaklaşımının önceki hudûs teorilerinden farkını belirgin kılmak için bu yaklaşımın dayandığı ilkeler şöyle sıralanabilir:

1- Sadrâ'nın birçok felsefî görüşünde etkisi görülen cevherî hareket teorisi, hudûs anlayışının da nirengi taşını oluşturmaktadır. Buna göre âlemin her zerresi özü itibariyle her an hareket halinde olup âlemde sürekli bir hudûs hali yaşanmaktadır. Öyle ki cevherden araza âlemde bulunan varlıkların hiçbiri iki 'an'a kalmaz. Böyle bir hudûsla her an yenilenen varlıklar elbette zaman içinde vücûda gelmektedirler. Zaman kavramı işte varlığın bu sürekli değişim ve yenilenmesinden soyutlanan bir kavram olduğundan hudûsun başlangıç zamanı bilinemez. Bu sorunun peşinden ne kadar geriye gidilirse gidilsin âlemin hudûs halinde olduğu görülecektir. Başka bir ifadeyle âlem hâdislerin silsilesinden müteşekkildir. Bu silsilede ilk hâdis olana hiçbir şekilde ulaşılamaz. ${ }^{99} \mathrm{Bu}$ tavzih doğal olarak bizi ikinci ilkeye götürmektedir.

2- Âlemi oluşturan her maddî cismin, özü itibariyle hareket etmesini ve bu hareketle hudûsa gelmesini sağlayan ezelî, ebedî ve kesintisiz olan ilahî feyzdir. Âleme hayat bahşeden bu ilahî feyzin, zaman içinde muayyen bir noktadan başladığını söylemek doğru değildir.60 Zira Allah'ın varlığıyla varolagelen bu feyz de ezelîdir. İlahî feyzle yenilenen tabiatın cevherî hareketinin mahsulü olan zaman ise bu kesintisiz ve sürekli olan ilahî feyzin niceliksel ifadesidir. Dolayısıyla ilahî feyzin başı ve sonu belli olmadığ gibi bu feyzle meydana gelen hudûsun da zamansal bir başlangıcı yoktur. Fakat ilahî feyzin ezelîliği ne münferit olarak mümkün varlıkların ne de bütün

58 Seyyid Celaleddin Aștiyânî, Şerh-ı Hâl ve Arâ-ı Felsefe-ı Molla Sadrâ, (Kum: Müessese-ı Bustan-ı Kitab, 1378/1999), 86-87. Sadrâ'ya göre âlemdeki sürekli yaratma Meşşaîlerin sandığı gibi cevherin arazlarında meydana gelen ve bütünüyle oluş ve bozuluş ile süren bir değişim veya İbnü'lArabî’nin âlemdeki her an yenilenme/yaratmayı ifade etmek üzere kullandığı halk-ı cedîd şeklinde değil, belki sonraki suretin önceki suretin tüm özelliklerini ihtiva ettiği daha üstün ve kâmil bir suret şeklinde gerçekleşir. ${ }^{58}$ Sadrâ, İbnü'l-Arabî'nin âlemdeki sürekli yaratılışı ve yenilenmeyi ifade eden halk-ı cedî̀ görüşünden etkilenmekle beraber, bu tür bir yaratma için İ̉nü'l-Arabî gibi soyunduktan sonra giyinme anlamina gelen لبس بعد خلع lebs bade hel' kavraminı tercih etmez. Sadrâ, cevherin bizzat özünde meydana gelen değişimi üst üste giyinme anlamına gelen لبس بعد لبس bade lebs veya el-fadileh ba'de'l-fadileh, el-kemâl favke'l-kemâl gibi kavramlarla ifade eder. İbnü'l-Arabî Eş'âriler'in araz için savundukları "araz iki zamana kalmaz" ifadelerini "mevcut iki zamana kalmaz" şeklinde revize ederek لبس بعد خلع kavramıla bir varlığın sürekli bir biçimde yok olup yeniden hayat bulduğunu ve bu yenilenme sırasında geride kalan her şeyin madum, sonraki varlığın ise bütünüyle yeni olduğunu savunur. Sadrâ ise cevherî bir hareketle kemale doğru ilerleyen varlığın peyderpey büründüğü suretlerde, sonraki sureti önceki suretin üstüne giydiğini ve onu içine alarak daha üstün bir surete ulaşırken herhangi bir şeyin madum olmadığını savunur. Karşılaştırmak için bkz. Molla Sadrâ, Esfâr, III: 112-113, 292; IV: 275, V: 345; İbnü'l-Arabî, Fusûsu'lHikem, trc. Hamza Kılıç, (İstanbul: İnsan Yayınları, 2014), 177-179; Muhammed Hacı Yusuf, İbnü'lArabî: Zaman ve Kozmoloji, trc. Kadir Filiz (İstanbul: Nefes Yayınları, 2016), 196-199.

59 Molla Sadrâ, Sadrüddîn Muhammed b. İbrâhîm b. Yahya Kavâmî Şînâzî, el-Meşấ'ir, thk. Henry Corbin, (Tahran: Kitaphane-i Tahûrî, 1363/1984), 64-65; Abdurresul Ubûdiyet, Deramedi bı Nizam-i Hikmet-i Sadrầ, (Tahran: Sazıman-1 Mutalaâ ve Tedvin-i Kutub-i Ulûm-i İnsanî Danişgâhha, 1394/2015), I: 384-385; Surûş, Evrenin Yatışmaz Yapısı, 94-95.

60 Molla Sadrâ, Esfâr, VII: 282. 
olarak âlemin ezelî olmasını gerekli kılar ${ }^{61}$ diyen Sadrâ ezelîlik ve kıdem sıfatlarını Allah'a has kılma noktasında taviz vermeyen bir tavır takınır.

3- Sadrâ'ya göre 'âlem' kavramı ilahî alanın dışında kalan mâsivâyı ve cismanî varlıkları ifade etmektedir. Tanrı'nın esmasının suretleri olan mufarık akıllar ve suretler ise ilahî alana ait olup 'âlem'in dişındadır. ${ }^{62}$ Cismânî olmayan bu soyut varlıklar daimî hudûs halinde olan âlemin zamansal ve mekânsal koşullarına tâbi değildirler.

4- $\quad$ Âlem hudûsa tâbi olan cüzlerinin mecmuasıdır. Cüzleri sürekli yenilenme halinde olan âlemin, cüzlerinin tâbi olduğu koşullardan bağımsız küllî yapısına özgü farklı bir durumda olması söz konusu değildir. Başka bir ifadeyle cüzleri hâdis olan küllî âlem de hâdis olmak durumundadır. ${ }^{63}$ 'Bütün'ün onu oluşturan tek tek öğelerden daha fazla bir mevcudiyete sahip olmadığını söyleyen Sadrâ'ya göre âlem tüm cüzleriyle zamanlı olaylardan asla arınık değildir. ${ }^{64}$ Dolayısıyla âlem teşekkül bulduğu cüzleriyle hâdistir.

Bu ilkelerden hareketle denilebilir ki Sadrâ'ya göre 'âlem' denilen varlık alanı içinde her şey zaman mecrası içinde akan bir hudûs halindedir. Âlem, tüm cüzleriyle sürekli bir yenilenme halinde her an yeniden yaratılmaktadır. Bu bağlamda âlem iki anda asla aynı durum üzerine sabit kalmayan yatışmaz ve cevval bir haldedir. Öncesiz ve kesintisiz olan ilahî feyzle başlayan yaratma için muayyen bir bidayet anı belirlenemediğinden hudûsun da başlangıç anı bilinemez. Yani âlem, öncesinde yokluk olan muayyen bir zaman diliminde yaratıldığ 1 anlamda hâdis değil, yaratmanın zaman mecrasında gerçekleştiği anlamda hâdistir. İlahî kitapların da âlemin zamansal bir hudûsla yaratıldığını söyleyen ${ }^{65}$ Sadrâ'nın zaman telakkisi hudûsu kendisiyle olan ve hiçbir zaman kesintiye uğramayan cevherî hareketin miktarı şeklindedir. Böyle bir hudûsun ve zamanın başlangıcı yoktur. Çünkü Allah var olduğundan beri yaratılış da varolagelmiştir. "O, her an yeni bir yaratmadadır." ${ }^{66}$ Allah her daim var olmuş ve olacaktır. O halde varlıkların hudûsu da her daim olmuş ve bu hudûsla beraber yaratma da hiçbir zaman kesintiye uğramamış ve uğramayacaktır. Allah'ın cömertliği asla kesintiye uğramayan ve sona ermeyen bir cömertliktir diyen Sadrâ, "Allah'ın nimetlerini saymaya kalksanız sayamazsınız"67 mealindeki ayeti de ilahî feyzle özdeşleştirdiği hudûsun başlangiçsız olduğuna delil olarak gösterir. ${ }^{68}$

Görüldüğü üzere hudûsun zamansal olduğunu söylerken Sadrâ, hudûsun muayyen bir zamanda başladığını kastetmemektedir. Ona göre hudûsun

\section{Molla Sadrâ, Esfâr, VII: 306}

Molla Sadrâ, Esfâr, VI: 315, VII: 297-298; a. mlf., Risaletu fi'l-hudûs, 112; a. mlf., Arşiyye, 232.

63 Molla Sadrâ, Esfâr, VII: 297; Ubûdiyet, Deramedi bı Nizam-ı Hikmet-i Sadrâî, I: 384; Surûş, Evrenin Yatışmaz Yapısı, 93.

64 Molla Sadrâ, Esfâr, III: 158.

65 Molla Sadrâ, Sadrüddîn Muhammed b. İbrâhîm b. Yahya Kavâmî Şîrâzî, el-Mezâhiru'l-ilâhiyye, tsh. Seyyid Muhammed Hamanei, (Tahran: Bunyâd-1 Hikmet- i Sadrâ, 1387/2008), 64; a. mlf., Esrâru'lâyât, thk. Muhammed Hacevî, (Tahran: Encümen-i Hikmet ve Felsefe, 1360/1981), 90.

66 Rahman, 55/29.

67 İbrahim, 14/34.

68 Molla Sadrâ, Esfâr, III: 149, VII: 122. 
zamansallı̆̆ı kelâmcılarla filozoflar arasında tartışma konusu olan âlemin yaratılışının başlangıç anını belirleme anlamında değildir. Onun hudûsun zamansal oluşundan kastı âlemin cevherî hareketinden elde edilen zamanın hudûsla olan zorunlu birlikteliğidir. Zira geçtiği üzere cevherî harekete göre âlemde bulunan her varlık özü itibariyle her an yenilenirken zaman, bu yenilenmenin ölçüsü olarak ona eşlik etmektedir. Dolayısıyla her an hudûs halinde olan âlemin hareket ve değişimi zamanla muayyen hale gelmektedir. Bu yaklaşımdan hareketle ilahî feyz ile âlemin yaratılışı/hudûsu arasında varoluşsal bir ilişki kurarak zamanı da bu ilişkinin ölçüsü olarak kabul ettiğimizde âlemin dışında bir zaman bulunmadığı için "âlem ne zaman yaratıldı?" sorusu da tıpkı "zaman ne zaman yaratıldı?" sorusu gibi güzaf olmaktadır. Başka bir ifadeyle âlemin ve zamanın varlığı eşzamanlı olarak başladığından ve âlemin varlığından önce zaman olmadığından var olması mümkün olmayan böyle bir dönem hakkında soru sormak yersizdir.

\subsection{Sadrâ'da Hudûsun Sabit ve Değişkenle İlişkisi}

Sadrâ, cevherî hareket teorisine dayanan hudûs anlayışına bağlı olarak metafiziğin çetin problemlerinden bir diğeri olan sabit ile değişkenin münasebeti meselesine de açılık getirmektedir. Değişken âlemin değişimden münezzeh olan yaratıcıya nasıl bağlanacağı, müşahede edildiği üzere önceki hudûs yaklaşımlarında da tartışmaların odağında yer almaktaydı. Nitekim Meşşâî filozoflar bu problemi aşmak için âlemi ay-üstü ve ay-altı olarak ayırarak ay-altı âlemdeki değişikliklerin ay-üstünde bulunan feleklerin hareketlerine bağlı olduğu bir âlem tasavvuru ortaya koymuşlardı. Mîr Dâmâd ise benzer bir biçimde dehr dediği aracı bir âlem kategorisi ile problemi çözmeye çalışmıştı. Kategorik âlem anlayışını kabul etmeyen Sadrâ, hareket-i cevherî teorisine dayanarak probleme çözüm bulmaya çalışır. Ona göre değişken olan bir malûl, hareket halinde olmayan ve harekete geçirilen bir nesne, illetine iki açıdan muhtaçtır: ilki yaratılma, ikincisi ise harekete geçme. Fakat tözü/cevheri itibariyle hareket halinde olan nesnelerde ise ikincisine ihtiyaç yoktur. Bu nesnelerin yaratılışı, cevherî hareketi de haiz olan bir yaratmadır. Başka bir ifadeyle yaratılmaları ile hareket etmeleri iki ayrı (mürekkeb) ihtiyaç değil belki basît bir ihtiyaç olup ilki, ikincisini içermektedir. Dolayısıyla bu nesnelerin yaratılışları bizzat 'hareket' ve 'akış' demektir. ${ }^{69}$ Sadrâ'nın konuyla ilgili ifadeleri şöyledir:

“Eğer bir şeyin değişimi, o şeyin zâtî sıfatı değilse, yani değişimi özünden kaynaklı değilse bu şey kendisini değiştirecek, yenileyecek başka bir sebebe ihtiyaç duyar. Ancak söz konusu şey, değişimin sebebini kendi özünde taşıyorsa kendisini yenileyecek haricî bir sebebe ihtiyaç duymaz. Sadece kendisini bu zâtî özelliklerini haiz bir şekilde yaratacak bir yaratıcıya ihtiyaç duyar. Şüphesiz varlığın özünde yenilenme ve seyelanı sağlayan bir durum vardır ki bize göre bu tabiattır. Başkalarına göre bu hareket ve zamandır. Her şeyin bir sabit bir de değişken yönü

69 Surûş, Evrenin Yatışmaz Yapısı, 101; Ferah Ramin, “Mebânî Sadrü’1 Müteellih el-Felsefiyye”, Felsefetu Sadrü'l-Müteellihîn eş-Şirâzî el- Mebânî ve'l-Mütemerkizât, (Beyrut: Darü'l-maârif al-hikemiye, 2008), 150. 
vardır. Tabiat sabit olmak bakımından (kaynağı itibariyle) 'mebde'e bağlı iken değişken yönüyle ise tabiattaki yenilenmeye ve hudûsa sebep olmaktadır. Tabiatın ana maddesi olan heyûla Allah tarafından yaratılmış olup suretiyle tabiatın sabit yönünü teşkil etmektedir. Bu maddenin yapısında ise potansiyel olarak yer alan imkânların gerçeklik kazanması cismânî varlıklarda hudûs ve zevallere sebep olur. İşte bu şekilde kadîm ile hâdis arasında bir ilişki hâsıl olur. Böylece ulemanın çözmekte aciz kaldığı bir problem çözüme kavuşmuş olur." 70

Aynı yöndeki benzer görüşlerini Mefâtihu'l-gayb adlı eserinde ise şöyle dile getirir:

“Biz kesin olarak biliyoruz ki; cismi bir mekândan başka bir mekâna, ya da bir nitelikten diğerine dönüştüren bir yatkınlık ve cismin onunla kaim olduğu bir güç vardır ki bu 'tabiat' denilen yetiden başka bir şey değildir."71

Âlemdeki değişimin kaynağını varlığın/tabiatın cevherinde taşıdığı yatışmaz ve cevval öze dayandıran Sadrâ, değişkeni sabite, hâdis olanı ise kadîme bağlayan gücün maddenin zatıyla yenilenen cevheri olduğunu savunur. ${ }^{72} \mathrm{Bu}$ yaklaşımda nedensellik zinciri varoluşsal olduğundan İbn Sînâ ve Mir Dâmâd'ta mahiyetin önceliği konusunda görülen problemler ortaya çıkmaz. İmkân, bu nedenle bir varoluşsal yoksunluk göstergesi olup zorunlu olan varoluşsal bir nedene bağlllıktır.73 Bu sebeple Molla Sadrâ'nın evrenin yaratılışına dair teorisi İbn Sînâ'nın salt mantıksal ve oldukça araçsal mahiyetçi yaratılış teorisi ile Mîr Dâmâd'ın zaman ötesi aracı ebedî yaratılış teorisini uzlaştıran bir yorum olarak görülebilir. ${ }^{74}$ Hatta bu uzlaşıya kelâmcıların zamansal hudûsu da eklenebilir. Kant gibi kimi filozofların metafiziğin en çetrefilli sorunu ve ebediyen çözülemez düğümü olarak niteledikleri75 bu çetin problemde Sadrâ'nın elini güçlendiren ve ona uzlaştırıcı bir çözüm bulma fırsatını veren kuşkusuz cevherî hareket teorisidir. Nitekim söz konusu teori bir yandan ona âlemin bir süreç olarak ezelî olduğunu ileri sürme diğer yandan ise ona her şey cevheri itibariyle devamlı bir değişim halinde olup bir an bile durmadığından âlemin zamanda yaratıldığını savunma imkânını vermektedir. ${ }^{76}$

Sadrâ'nın cevherî hareket teorisine dayanan hudûs yaklaşımıla önceki yaklaşımlarda görülen kimi çıkmazları izale etmesine rağmen problemi nihaî olarak çözdügünü söyleyemeyiz. Zaman, hareket ve ilahî feyz arasında kurduğu muhkem bağ elbette probleme farklı bir boyut kazandırmış ve âlemin dışında müstakil bir zamanın var olamayacağını söylemekle kelâmcıların zamansal hudûs hakkındaki iddialarını temelden sarsmıştır. Önceki yaklaşımlarda da görüldüğü

\footnotetext{
Molla Sadrâ, Esfâr, III: 68-69; a.mlf, Risaletu fi'l-hudûs, 51.

Molla Sadrâ, Mefâtihu'l-gayb, 388.

Molla Sadrâ, Sadrüddîn Muhammed b. İbrâhîm b. Yahya Kavâmî Şîrâzî, Kitabü'l-Meşấir: Metafiziğe Giriş, nşr ve trc. A. Kamil Cihan, Fevzi Yiğit, Salih Yalın, (İstanbul: Endülüs Yayınları, 2019), 166.

73 Molla Sadrâ, Hudûsu'l-âlem, 191-193.

74 Sajjad H. Rizvî, "Time and Creation: The Contribution of Some Safavid Philosophies" RPF (Revista Prtuguesa de Filosofia, n. 62 (2006), 730.

75 Immanuel Kant, Critique of Pure Reason. trc. Norman Kemp Smith, (New York: Palgrave Macmillan, 2003), 396.

76 Fazlurrahman, The Philosophy of Mulla Sadra, (Albany: State University of New York, 1975), 111.
} 
üzere Sadrâ'nın kastettiği cismanî âlemin zamansal hudûsu konusunda ciddi bir fikir ayrilığı yoktur. Gerek zamansal hudûsta gerek zâtî hudûsta gerekse dehrî hudûsta cismanî varlıkların zaman içinde yaratıldığına dair bir itiraz söz konusu değildir. Asıl ihtilaf Meşşâ̂lerin ay-üstü âlem ile Mîr Dâmâd'ın dehr âleminde bulunan akıllar ve semavî varlıkların hudûsunun mahiyeti hakkındadır. Nitekim Sadrâ hudûs konusunda Meşşâ̂lerin ay-üstü ve ay-altı âlem ayrımını kabul etmese de varlıkları cismanî ve mücerret olarak ayırmakta ve mücerret varlıkları âlemin sınırının dışında tutarak bu varlıkları zamandan münezzeh olan tanrısal alana ait olarak görmektedir. Bu tür varlıklar bi'l-fiil akıl derecesine yükseldikleri için Zat-i İlâhiden ayrı bir varlıkları yoktur. ${ }^{77}$

Sadrâ, cevherî hareketle hudûsu bütünleştirdiğinden değişimden uzak, istikrar makamı olan mukaddes tanrısal sahada hareketin ve zamanın olmadığını, dolayısıyla hudûsun gerçekleşmediğini savunmaktadır. Zira ona göre hareket, potansiyel bir durum içeren ve bütünüyle maddeden soyutlanmayan varlıklar için geçerlidir. Maddeden bütünüyle soyutlanmış ve herhangi bir fakr ve ihtiyaç hali bulunmayan mücerret akıllar ile Allah'ın isim ve sıfatları ise hareket ve zamandan muaftırlar. Hudûs, Sadrâ'ya göre ilahî feyzin tabiî sonucu olarak zamanda gerçekleştiği için bu feyz, hareketten ve zamandan münezzeh olan ilahî isim ve sıfatların makamında herhangi bir hudûsa sebep olmamaktadır. Başka bir ifadeyle ilahî isim ve sıfatlar ile mufarık akıllar, varlıklarında tahakkuk etmeyen herhangi beklenti ve kuvve bulunmadığı için hareketten ve zamandan muaf olup Zat-1 İlâhi ile aklî bir ittisal ile bağlıdırlar. ${ }^{78}$ Dolayısıyla hudûs, cismaniyetten henüz bütünüyle sıyrılamayıp bu sahaya dâhil olmayan varlıklar üzerine caridir.

\section{Sonuç}

Hudûs-kıdem problemine dair ortaya konulan yaklaşımlara toplu olarak baktığımızda Molla Sadrấnın yorumu da dâhil bütün yaklaşımlarda zaman kavramının tıpkı bir nirengi taşı gibi bütün tartışmaların seyrini belirleyen ve bu yaklaşımları yekdiğerinden tefrik eden bir işlev gördüğünü söyleyebiliriz. Nitekim probleme dair ortaya konulan görüşlerde ihtilafın asıl kaynağı, zaman kavramına yükledikleri anlamla alakalıdır. Gerek kelâmcılar gerekse filozoflar Tanrı'nın âlem ve zamandan önceliğini kabul etmektedirler. Tek fark kelâmcıların âlemin sadece Tanrı'nın varlığına değil aynı zamanda O'nun iradesine de bağlı olduğuna vurgu yaparak âlemin yaratılışından önce bir yokluk döneminin de olabileceğine inanmalarıdır.

Sadrâ, âlemin zamanda yaratıldığını savunurken hareket-i cevherî bağlamında zaman mefhumuna yüklediği anlam üzerinden bir çözüm sunmaktadır. Nitekim zamansal hudûstan kastının kelâmcıların savunduğu anlamda üzerinde zamansal yokluğun geçtiği bir hudûs olmadığını israrla vurgular. Hareket ve zamanın, seyyal varlığın birer boyutu olarak ondan ayrı bir mevcudiyetlerinin bulunmadığını ileri süren Sadrâ'ya göre varlık, cevheri itibariyle devamlı bir

77 Molla Sadrâ, Risaletu fi'l-hudûs, 139-141.

78 Molla Sadrâ, Risaletu fi'l-hudûs, 144-145. 
değişim ve yatışmaz bir cevvaliyete sahip olduğundan zaman öncesi bir zamanın veya hareketin bizzat kendisi anlamına gelen yaratmanın olmadığı mevhum bir zamanın varlığı söz konusu olamaz. Âlemi ay-üstü ve ay-altı olarak ayıran Meşşâilerin zâtî hudûsu ile Mîr Dâmâd'ın sermed, dehr ve zaman şeklinde âlemi ontolojik bir konumlandırmayla ayıran dehrî hudûsunun da kategorik âlem anlayışlarını kabul etmeyen Sadrâ, "âlem" kavramını ilahî alanın dışında kalan mâsivâyı ve cismanî varlıkların tümünü kapsayacak şekilde kullanır. Âlem bir bütün olarak hareket ve zamana tâbi iken âlemin dişında kabul ettiği Allah ve O'nun esmasının suretleri olan ve zatından ayrı olmayan mufarık akıllar ise maddeden mücerret olduklarını ve dolayısıyla hareket ve zamanın geçerli olmadığı Tanrısal alanda ne zatî ne de dehrî bir hudûsun yaşanmadığını savunur.

Tanrı'nın âlemden önceliğinin zamansal mı yoksa zâtî veya mantıkî bir öncelik mi olduğu konusunda bir kısırdöngüye dönüşen tartışmaların asıl sebebi kanaatimizce zamanın mahiyeti konusundaki görüş ayrılıklarıdır. Dolayısıyla hudûs ve kıdem probleminin kaderinin son derece girift ve soyut olan zaman kavramına bağlı olduğu görülmektedir. Metafiziğin en girift konularından biri olan hudûs-kıdem probleminin tüm insanî çabalara rağmen hala bir muamma olması -Kant'a göre belki de ebediyen çözülemeyecek olması - kanaatimize göre zamanla kayıtlı olan insan zihninin zaman ötesi bir alanı veya zamansızlığı kavramaktan aciz oluşuyla izah edilebilir. Nitekim hudûs-kıdem probleminde asıl ihtilaf, kanaatimizce öncelik ve sonralık gibi zamansal kavramların zaman ötesi olarak tabir edilen bir varlık alanı için de kullanılması ve zamanla kayıtlı olan insan zihninin kavramsal repertuarının sınırlılığına rağmen zamansızlığı idrak etmeye zorlanmasından kaynaklanmaktadır. Bu sebepten olacak ki İslâm düşünce geleneğinde hudûs probleminin çözümüne dair mezkûr teorilere rağmen hâlâ zihnimizde hudûsla ilgili sorular bütünüyle cevap bulmuş değildir. Bununla birlikte Sadrâ'nın kendinden önceki düşünce geleneğinin müktesebatından alabildiğine yararlanarak önemli inkişaflar gerçekleştirdiğini ve önümüze geliştirmemiz ve yeni inkişaflarla buluşturmamız gereken bir yol açtığını söylemeliyiz. Bu istikamette ilerleyerek Sadrâ'nın hudûs yorumunu yeni bilimsel ve felsefî nazariyelerle yorumlayabilirsek bu girift meselenin üzerindeki esrarlı perdeyi belki biraz daha aralamış oluruz.

\section{Kaynakça}

Açıkgenç, Alparslan. "İslâm Düşüncesinde Zaman Anlayışının Felsefî Tahlili". Uluslararası İslâm Medeniyetinde Zaman Sempozyumu. Ed. Bilal Kuşpınar. I: 19-28. (Konya: Selçuklu Belediyesi, 2015).

Aştiyânî, Seyyid Celaleddin. Şerh-ı Hâl ve Arâ-ı Felsefî Molla Sadrâ. Kum: Müessese-1 Bustan-1 Kitab, 1378/1999.

Atay, Hüseyin. Farâbî ve İbn Sinấya Göre Yaratma. Ankara: Ankara Üniversitesi İlahiyat Fakültesi Yayınları, 1974.

Cürcânî, Seyyid Şerif Ali b. Muhammed. Kitabu't-Ta'rifât. thk. Muhammed Abdurrahman el-Mer'aşlî. Beyrut: Dârü'n-Nefâis, 2003. 
Dinanî, Gholam Huseyin İbrahim. Muamma-yı Zaman ve Hudûsı Cihân. Tahran: Muessese-1 Pijuheşi-i Hikmet ve Felsefe-i İran, 2014.

Doru, Mehmet Nesim. "Mîr Dâmâd'ın Hudûs Konusunda İbn Sînâ'ya Yönelttiği Eleştiriler ve Hudûs-u Dehrî Görüşü". Felsefe Dünyası. 56 (2012/2): 249-273.

Bâkıllânî, Ebu Bekir. Kitâbü't-Temhîd. Beyrut: Dârü'1-Meşrık, 1957.

Fazlurrahman. The Philosophy of Mulla Sadra. Albany: State University of New York, 1975.

Fazlurrahman. "Mîr Dâmâd'ın Hudûs-i Dehrî Kavramı: Safeviler Dönemi İran'da Tanrı-Âlem İlişkisi İle İlgili Çalışmalara Bir Katkı". trc. M. Nesim Doru. İstanbul Üniversitesi Ilahiyat Fakültesi Dergisi. 27 (2012): 231-246.

Gazzâlî, Ebû Hâmid. Tehâfütü'l-felasife. thk. Süleyman Dünya, Tahran: Şems-i Tebrizî, 1382/2003.

Hacı Yusuf, Muhammed. İbnü'l-Arabî: Zaman ve Kozmoloji. trc. Kadir Filiz. İstanbul: Nefes Yayınları, 2016.

Izutsu, Toshihiko. "Mîr Dâmâd ve Metafiziği". trc. M. Nesim Doru. Eskiyeni. 30 (Bahar 2015), 175-184.

İbn Rüşd, Ebü'l-Velîd Muhammed b. Ahmed. Faslu'l-makâl. Beyrut: Daru'l-Meşrık, 1986.

İbn Sînâ, Ebû Alî. el-İşârât ve't-tenbîhât. (Nasıruddin et-Tûsî'nin Şerhli Metni). Kum: Neşru'l-Belağe, 1375/1996.

İbn Sînâ, Ebû Alî. el-Mebde' ve'l-me'âd. tsh. A. Nûrânî. Tahran: Müessese-i Mütâla'ât-1 İslâmî, 1363/1984.

İbn Sînâ, Ebû Alî. eş-Şifâ: el-İlâhiyât. thk. Said Zayed, Kum: Mektebetü Ayetullah elMer'aşî, $1404^{\mathrm{HK}}$.

İbn Sînâ, Ebû Alî. et-Ta'likât. thk. Abdurrahman Bedevî. Beyrut: Mektebü'l-İlâmi'l İslâmî, $1404^{\mathrm{HK}}$.

İbnü'l-Arabî. Fusûsu'l-Hikem. trc. Hamza Kılıç. İstanbul: İnsan Yayınları, 2014.

Kant, Immanuel. Critique of Pure Reason. trc. Norman Kemp Smith. New York: Palgrave Macmillan, 2003.

Kaya, Cüneyt. Varlık ve İmkân. İstanbul: Klasik Yayınları, 2011.

Kılıç, Muhammed Fatih. “İbn Sinnânın Hudûs Yorumu”. Beytulhikme: An International Journal of Philosophy. 1/2 (2011): 105-132.

Kılıç, Muhammed Fatih. “İbn Sînâ'nın Kelâmcıların Hudûs Görüşüne Yönelttiği Eleştiriler". Divan: Disiplinlerarası Çalışmalar Dergisi. 15/28 (2010/1): 115-134.

Leaman, Oliver. İslâm Felsefesi: Giriş. trc. Şamil Öçal. İstanbul: Hece Yayınları, 2014.

Mir Dâmâd. el-İmazât. Musannefât-ı Mîr Dâmâd içinde, thk: Abdullah Nurânî.

Tahran: İntişârât-1 Encümen-1 Asâr ve Mefâhir-i Ferheng, 1381/2002. 
Mir Dâmâd. el-Kabasât. Thk. Mehdi Muhakkik vd. Tahran: İntişârât-1 Danişgâh-1 Tahran, 1367.

Molla Sadrâ, Sadrüddîn Muhammed b. İbrâhîm b. Yahya Kavâmî Şîrâzî. elHikmetu'l-müteâliye fi esfâri'l-aklîyyeti'l-erbaâ. Beyrut: Dar-1 Ehya-ut-Turas, 1981.

Molla Sadrâ, Sadrüddîn Muhammed b. İbrâhîm b. Yahya Kavâmî Şîrâzî. el-Meşấir. thk. Henry Corbin. Tahran: Kitaphane-i Tahûrî, 1363/1984.

Molla Sadrâ, Sadrüddîn Muhammed b. İbrâhîm b. Yahya Kavâmî Şîrâzî. Kitabü'lMeşấir: Metafiziğe Giriş. nşr ve trc. A. Kamil Cihan, Fevzi Yiğit, Salih Yalın. İstanbul: Endülüs Yayınları, 2019.

Molla Sadrâ, Sadrüddîn Muhammed b. İbrâhîm b. Yahya Kavâmî Şîrâzî. elMezâhiru'l-ilâhiyye. tsh. Seyyid Muhammed Hamanei. Tahran: Bunyâd-1 Hikmet- i Sadrâ, 1387/2008.

Molla Sadrâ, Sadrüddîn Muhammed b. İbrâhîm b. Yahya Kavâmî Şîrâzî. Esrâru'lâyât. thk. Muhammed Hacevî. Tahran: Encümen-i Hikmet ve Felsefe, 1360/1981.

Molla Sadrâ, Sadrüddîn Muhammed b. İbrâhîm b. Yahya Kavâmî Şîrâzî. etTasavvur ve't-Tasdik. Kum: İntişârât-1 Bidar, 1371/1992.

Molla Sadrâ, Sadrüddîn Muhammed b. İbrâhîm b. Yahya Kavâmî Şîrâzî. Hudûsu'lâlem. thk. Seyid Hüseyin Museviyân. Tahran: İntişârât-1 Mevlâ, 1366/1987.

Molla Sadrâ, Sadrüddîn Muhammed b. İbrâhîm b. Yahya Kavâmî Şîrâzî. Mefâtihu'lgayb. thk. Muhammed Hacevî. Tahran: Müessese-i Tahkikât-1 Ferhengî, 1363/1984.

Molla Sadrâ, Sadrüddîn Muhammed b. İbrâhîm b. Yahya Kavâmî Şîrâzî. Risaletu fi'l-hudûs. thk. Seyyid Hüseyin Museviyân. Tahran: Bunyâd-ı Hikmet-i İslâmî, 1378/1999.

Mutahharî, Murtaza. Felsefe Dersleri 1. trc. Ahmet Çelik. İstanbul: İnsan Yayınları, 1997.

Ramin, Ferah. "Mebânî Sadrü'l Müteellih el-Felsefiyye". Rekâizu Felsefeti Sadrü'lMüteellihîn eş-Şirâzî el-Mebânî ve'l-Mütemerkizât. Beyrut: Darü'l-maârif al-hikemiye, 2008. )

Rizvî, Sajjad H.. "Time and Creation: The Contribution of Some Safavid Philosophies" RPF (Revista Prtuguesa de Filosofia, 62 (2006): 713-737.

Surûş, Abdülkerim. Evrenin Yatışmaz Yapısı. trc. Hüseyin Hatemi. İstanbul: İnsan Yayınları, 2008.

Topaloğlu, Bekir. İslâm cılarına ve Filozoflarına Göre Allah'ın Varlığı (İsbat-ı Vacib). Ankara: DİB Yayınları,1998.

Topaloğlu, Bekir. "Hudûs". Diyanet İslâm Ansiklopedisi. 18: 304-309. İstanbul: TDV Yayınları, 1998.

Ubûdiyet, Abdurresul. Deramedi bı Nizam-ı Hikmet-i Sadrâî. Tahran: Sazıman-1 Mutalaâ ve Tedvîn-i Kütüb-i Ulûm-i İnsanî Danişgâhha, 1394/2015. 